IZA DP No. 4908

On the Role of Sectoral and National Components in the Wage Bargaining Process

Christian Dreger

Hans-Eggert Reimers

April 2010 


\title{
On the Role of Sectoral and National Components in the Wage Bargaining Process
}

\author{
Christian Dreger \\ DIW Berlin \\ and IZA \\ Hans-Eggert Reimers \\ Hochschule Wismar
}

Discussion Paper No. 4908

April 2010

IZA

P.O. Box 7240

53072 Bonn

Germany

Phone: +49-228-3894-0

Fax: +49-228-3894-180

E-mail: iza@iza.org

\begin{abstract}
Any opinions expressed here are those of the author(s) and not those of IZA. Research published in this series may include views on policy, but the institute itself takes no institutional policy positions.

The Institute for the Study of Labor (IZA) in Bonn is a local and virtual international research center and a place of communication between science, politics and business. IZA is an independent nonprofit organization supported by Deutsche Post Foundation. The center is associated with the University of Bonn and offers a stimulating research environment through its international network, workshops and conferences, data service, project support, research visits and doctoral program. IZA engages in (i) original and internationally competitive research in all fields of labor economics, (ii) development of policy concepts, and (iii) dissemination of research results and concepts to the interested public.
\end{abstract}

IZA Discussion Papers often represent preliminary work and are circulated to encourage discussion. Citation of such a paper should account for its provisional character. A revised version may be available directly from the author. 
IZA Discussion Paper No. 4908

April 2010

\section{ABSTRACT}

\section{On the Role of Sectoral and National Components in the Wage Bargaining Process}

This paper provides an empirical analysis on the determination of wages at the sectoral level in main industrial economies. Nominal wages are bargained between labour unions and employers in imperfect competitive markets, where spillovers across sectors might occur. Using a principal component approach, sectoral wage growth rates are separated into common and idiosyncratic components. This defines the relative role of national and sector specific conditions in the wage determination process. The common component is highly relevant especially in continental Europe, and is more visible for manufacturing than for services sectors. It reflects national inflation and productivity growth, while labour market tightness is negligible. The weight of the macroeconomic environment has declined in recent years. Wage growth tends to be more in line with idiosyncratic conditions like sectoral productivity and prices, probably due to the ongoing globalization of markets.

JEL Classification: $\quad$ C22, C23, E24

Keywords: $\quad$ sectoral wages, wage spillovers, common factors

Corresponding author:

Christian Dreger

DIW Berlin

Mohrenstr. 58

10117 Berlin

Germany

E-mail: cdreger@diw.de 


\section{Introduction}

The aim of this paper is to present evidence on the role of sectoral and national components in the process of wage formation in continental European (Germany, France and Italy) compared to Anglosaxon countries (UK and US). Wages are crucial for determining the employment level in an economy. High weights of sectoral conditions in the wage determination process can relief the reallocation of labour in case of asymmetric shocks. In most industrialized countries wages are bargained between unions and employers or employer organizations. They are negotiated on the sectoral level, with an increasingly role for bargaining at the individual firm level (Du Caju, Gautier, Momferatou and Ward-Warmedinger, 2008). Wage bargaining in continental Europe can be characterised by a regulated system, with a high level of collective agreement coverage. In contrast, the system in the Anglosaxon countries is highly deregulated, with low coverage levels.

The development of wages in one sector might be also infuenced by wages bargained at specific other sectors. In Germany, wages negotiated by the metal workers union often have a signalling function for the whole economy, and have caused significant wage spillovers to other sectors. According to the Scandinavian inflation model, wage setting in sectors exposed to international competition should influence wage setting in the sheltered sectors (Aukrust, 1977, Friberg, 2003).

Due to the Calmfors and Drifill (1988) hypothesis, both highly centralized and decentralized wage bargaining systems are expected to increase the employment level, while intermediate forms will exert a negative impact. On the one hand, wage setting institutions might be more aware of the macroeconomic costs of agreements in centralized 
bargaining systems (Calmfors, 1993). Therefore, they could pursue a moderate wage policy to avoid negative externalities in terms of rising unemployment and inflation. In this respect, the introduction of the euro area might have had an adverse effect, as it could have reduced the inflationary perceptions of unions. As they operate at a national level, they could take less care about area wide inflation (Cukierman and Lippi, 1999, Grüner and Hefeker, 1999). On the other hand, flexible wage formation raises the ability of the economy to absorb shocks. This requirement has become more relevant in a fast changing economic environment due to the globalization of markets. In addition, national economic policies have become less important in particular in Europe. Exchange rate or monetary policies are no longer at the disposal of individual euro area member states and fewer opportunities for independent fiscal policies limit the capacity of the economies to react against adverse shocks. Hence, wages have to bear a higher part of the adjustment process (Frankel and Rose, 1998). As the financial crisis has led to a substantial increase in unemployment in many countries, this role has become even more important.

This paper examines to what extent wage developments are driven by common (transsectoral) or idiosyncratic (sector specific) components, and whether the relevance of these components have shifted over time. If wage bargaining is decentralized, sector specific variables dominate, and wages are closely related to individual market conditions. In more centralized bargaining systems, previous wage settlements may permeate throughout the economy. Industry shocks can take longer to affect wages even though the environment has changed. Due to advances in economic integration, competition has intensified in many branches. Thus, the weight of transsectoral factors in the determination of wages is expected to decline. 
This presumption is examined on the base of a large panel dataset for the period 1977 to 2007. Data are available for 25 manufacturing and services sectors. The common components are extracted from sectoral wage inflation rates by factor analysis. The results reveal a relatively high degree of centralization of wage bargaining especially in continental Europe: the first common component is often able to explain more than 70 percent of overall wage fluctuations. The role of sectoral conditions like industrial productivity and inflation is rather minor. Common components are less important for wage formation in the Anglosaxon countries. Moreover, wage spillovers appear to be more pronounced in manufacturing sectors when compared to services. For all countries covered in the analysis, an increase in the relevance of sectoral forces can be observed since the 1990s.

The paper is organized as follows: In section 2 the wage bargaining model in imperfect competitive markets is reviewed, taken nominal wage spillovers across the sectors into account. Data issues are discussed in section 3, and the empirical analysis is presented in section 4. Section 5 concludes.

\section{Wage bargaining in a market-institutional framework}

The existence of wage spillovers is consistent with standard hypotheses of wage determination and with institutional theories that emphasize wage leadership or the existence of historical wage differentials (Eckstein and Wilson, 1962, Addison and Burton, 1979). For a key group of industries, changes of wages are determined by sectoral conditions. If markets are not perfectly competitive, product rents can be shared between firms and workers, depending on their relative bargaining power. The latter is related to the degree 
of labour market tightness. Higher unemployment will ceteris paribus increase the competition for job vacancies, with probably adverse effects on wage demands of insiders. Outside a key group of industries, wages are determined by wage spillovers.

Due to the important role of collective agreements, the wage equation is specified in a bargaining framework. Nominal wages are negotiated at the sectoral level between trade unions and firms or their organizations, see for example Layard, Nickell and Jackman (1991), Nickell, Vainiomaki and Wadhwani (1994) and Lever and Marquering (1996). Firms maximize profits and unions maximize expected income for their members, who are the incumbent employees. It is assumed that the firms face imperfect competition in the product market, where the demand for goods is subject to exogenous shocks. The production technology can be described by a Cobb Douglas function with constant returns to scale, where capital $K_{i}$ and employment $N_{i}$ are the input factors for the ith sector. The bargaining parties agree about nominal wages. Based on the negotiated wages, firms set prices $P_{i}$ and determine the levels of output as well as labour and capital as input factors. By maximizing a Nash bargaining function, Layard, Nickell and Jackman (1991) give a mark up wage equation

(1) $\quad 1-\frac{A}{W_{i}}=\frac{1-\alpha \kappa_{i}}{\varepsilon\left(W_{i}\right)+\alpha \kappa_{i} / \beta_{i}}$,

where $W_{i}$ denotes the wage of the $i$ th sector, $A$ is the alternative income, $\alpha$ labour intensity, i.e. capital per unit of labour, $\kappa_{i}$ the degree of competition in the respective product market, $\varepsilon$ the absolute elasticity of survival with respect to the negotiated wage, which depends on the probability of a union member to stay employed in the subsequent pe- 
riod (the probability of survival) and the employment level, and $\beta_{i}$ the sector bargaining power of unions. Alternative income is specified as

$$
A=(1-\theta(u)) W+\theta(u) B \quad, \quad 0<\theta<1
$$

where $W$ is the wage rate in the overall economy, $B$ denotes unemployment benefits and $\theta(u)$ is the probability that an employee made redundant does not find a job elsewhere in the economy. The probability to stay in unemployment rises with the unemployment rate $u$. By substituting (1) into (2) we obtain

$$
1-\frac{W}{W_{i}}[1-\theta(u)(1-b)]=\frac{1-\alpha \kappa_{i}}{\varepsilon\left(W_{i}\right)+\alpha \kappa_{i} / \beta_{i}}
$$

where $b=B / W$ is the unemployment benefit ratio. This equation states that the mark up depends on the unemployment benefit ratio and the probability to find a new job. To investigate the impact of explanatory variables $\left(P_{i}, K_{i}, N_{i}, W, b, u\right.$ and $\left.\kappa_{i}\right)$ on the determination of sectoral wages the total differential of equation (3) is explored. Denoting the logs of the variables by lower case characters, this leads to

$$
d w_{i}=\lambda\left[d p_{i}+(1-\alpha)\left(d k_{i}-d n_{i}\right)\right]+(1-\lambda)\left[d w+\gamma_{1} d b+\gamma_{2} d u\right]+\gamma_{3} d \kappa_{i}+\gamma_{4} \beta_{i}
$$

where $p_{i}$ is the sector product price. Coefficients are given in the appendix. This relationship is the justification for writing sector wages as a log linear approximation of internal and external (macroeconomic) factors, competition in the product market and union bargaining power. The equation also demonstrates that the weight $\lambda$ of internal factors and $1-\lambda$ of external factors add up to unity. Furthermore, it can be shown that 
unemployment exerts a negative impact on the wage rate, while unemployment benefits and the bargaining power are expected to enter with a positive sign (see Nickell, Vainiomaki and Wadhwani, 1994 and Lever and Marquering, 1996). The unemployment rate, the overall wage rate and the unemployment benefit ratio reflect the opportunities of employees outside the respective sector. The higher the overall wage rate, the unemployment benefit ratio or the lower the unemployment rate, the lower are the costs for employees of quitting the sector and searching for a job elsewhere. Turning to the internal factors a rise in the sectoral output price, in the capital stock or a decline in the number of employees reduces the expected lay-off rate, thereby enabling the firm`s work force to increase the wage claim (Graafland and Lever, 1996). The impact of product market competition on wages is ambiguous. On the one hand side, an increase in market power raises wages because unions can expropriate part of the rents. On the other hand, there is a smaller probability of survival, as output and employment are reduced in monopolistic competitive markets. Equation (4) is the basis for the empirical analysis. In a stochastic environment, nominal wages essentially depend on both inside factors, such as industry prices and productivity, as well as outside factors, such as wage aggregates and the unemployment rate.

\section{Data issues}

Data at the sectoral level are taken from the EU KLEMS database, see O’Mahony and Timmer (2009) and are available at http://www.euklems.net. Industries are classified according to the International Standard Industrial Classification (ISIC) scheme. The analysis is done for the largest continental European (Germany, France, and Italy) and the Anglosaxon economies (UK and US). Hourly nominal wages per employee are con- 
structed by dividing nominal labour compensation of employees through the number of hours worked. Note that this concept refers to effective wages, since bargained wages are not reported at the sectoral level. Effective wages might differ from their bargained counterparts by the wage drift, i.e. a wedge due to overtime premia and gratifications. To the extent that effective and bargained wages are cointegrated, effective wages can be seen as a proxy for the latter. In addition, labour productivity per hour (real GVA divided by hours worked) and the GVA deflator (1995=100) are available for individual sectors. In case of the competition variables, no information is available for individual sectors. In the following, they are reflected in a constant.

-Table 1 about here-

Overall, the analysis is based on 25 industries at the annual frequency covering the time span 1977-2007. About 13 (10) branches can be classified as manufacturing (services) sectors. See Table 1 for the complete list of sectors. Macroeconomic series cover national labour productivity per hour, consumer and producer price indices, and the benefit replacement rate. See also Bårdsen, Eitrheim, Jansen and Nymoen (2005) and Peeters and Den Reijer (2008) on the selection of these variables in the determination of nominal wages. The unemployment rate is from the AMECO database of the EU Commission. Labour productivity is in logs. Consumer and producer price inflation (annual changes of the respective indices) and unemployment are measured in percent. The benefit replacement rate is defined as the ratio of unemployment benefits to the wage in the overall economy and is obtained from the OECD. Wages and productivity enter the 
analysis in first differences, and inflation, unemployment and the benefit replacement rate in levels. Thus, all series appear to be stationary. This can be confirmed by panel unit root tests ${ }^{2}$.

\section{$4 \quad$ Empirical results}

The first step is to establish some basic facts about sector wage developments for each country. Table 2 displays the mean and the dispersion of nominal wage growth, which is measured by the coefficient of variation. The values of these statistics are given over the whole period and two subsamples, 1977-1990 and 1991-2007, the latter broadly related to the period of globalization.

-Table 2 about here-

Annual nominal wage growth has declined in the latter period, where the decrease has been most pronounced in Italy and France. Wage inflation differentials between manufacturing and services sector are not very huge. The dispersion has increased both for manufacturing sectors and services. In relative terms the increase has been larger in continental Europe than in the Anglosaxon countries. This points to the lower relevance of common factors in the wage determination process. The results are broadly in line with survey evidence obtained from central bank experts (Du Caju, Gautier, Momferatou and Ward-Warmedinger, 2008).

\footnotetext{
${ }^{2}$ Results not reported in the paper are available from the authors upon request.
} 
According to the market institutional model of wage determination, wage inflation can be traced to sectoral and transsectoral forces. The latter are captured by the first principal components. They constitute the common element in nominal wage inflation. It may have a different weight in the bargaining processes of individual sectors.

The number of principal components can be estimated by information criteria, see Bai and Ng (2002). The evidence is not very conclusive at this point, as the number of common components does not seem to be unique. While Akaike based measures usually identify four components, which is also the maximum specified in the analysis, Bayesian criteria favour one or two principal components. Note that even the first principal component can be seen as sufficient to approximate the national factor, which accounts for a large share of the total variance of sectoral wage inflation. This is most striking for Italy, where the first component is able to represent about 82 percent, compared to 4 percent attributed to the second most important component (see Table 3). The subsequent analysis is done with the first two principal components per country. This choice is not critical for the results, as the findings can be easily replicated when a different number of principal components are used.

-Tables 3 and 4 about here-

In general, wage spillovers tend to be higher in continental European, and lower in the Anglosaxon economies. For example, the first two principal components are able to represent 80 percent of the total variation in nominal wage growth in France. For the UK and US, this share is only about 60 percent. The hypothesis of a wage leadership of 
a particular sector is not confirmed, as the loading coefficients do not reveal strong conspicuities. For example, the loading coefficients differ not very much across sectors (see Table 4).

Note that the cumulative proportion of the variance attributed to principal components is not constant over time (Table 3). In line with the higher dispersion of wage inflation across branches, the shares have decreased in the second sample. This pattern can be detected for both manufacturing and services sectors, and appears to be most visible in the Anglosaxon countries, but also in France and in Italy. Compared to the other countries, a decline cannot be detected in Germany. Note that the overall tendency points to persistent differences of sectoral wage inflation. If wage growth tends to be equalized across sectors, the share attributed to principal components will converge to 1 , while the dispersion will converge to 0 .

The decrease in the contribution of common components is most notable in France. According to Coelli, Fahrer and Lindsay (1994) the French wage dispersion has been outstanding stable in the 1970s and the 1980s compared to other OECD countries, as wage setting institutions did not change substantially. Since the 1990s, the trade-off between real wages and unemployment has improved, probably due to a gradual change in the preference of unions towards a higher employment level (Estevao and Nargis, 2005). In addition, there has been a decreasing trend in union density, and a lower bargaining power of unions, see Heckel, Le Bihan and Montores (2008). The different experience in France and Germany might be also related to the process of European monetary integration. While competitive devaluations of the domestic currency have been observed in the former period in France, they have not been deployed in Germany. Thus, the higher exchange rate stability implied a higher burden of adjustment for French firms, leading 
to higher wage divergence across sectors. The large persistence in Germany might be related to the fact that the introduction of the euro has changed the environment. Wage increases have been very moderate since then. The wage moderation took place in the manufacturing as well in the services sectors, and has been supported by economic policies. In contrast, Anglosaxonian countries can use the exchange rate to restore their international competiveness.

-Figure 1 about here-

To investigate the relative role of sectoral and national factors in the process driving wage inflation, changes of sectoral wages are regressed on a constant, the common component and sectoral variables. To construct the common component, the first two principal components are weighted according to their eigenvalues. The first principal component dominates, as it has often a weight of 90 percent. The weight is slightly lower for the Anglosaxon countries. To save degrees of freedom, the sum of productivity growth and inflation enters as the sectoral determinant. The equations are estimated at the sectoral level. A restriction is embedded to ensure that the weights of national and sectoral regressors add up to unity, according to equation (4). The weights of the common component are displayed in Figure 1, where heteroscedasticity consistent standard errors fluctuate around 0.1 . In general, the weight of the national component is higher for the manufacturing sectors (sectors 03-15, see figure 1). The most striking exception is financial intermediation (20), where the macroeconomic environment receives a relatively high weight. In contrast, its weight is particularly low for public services. Hence, 
models for wage inflation in the public sector should not be based on economy-wide conditions.

- Table 5 about here-

Further analysis reveals that the common component can be linked to macroeconomic developments to a large extent, see Table 5. In particular, the national component is driven by consumer price inflation and labour productivity growth. This coincides with the long run input rule of competitive markets that nominal wages are equal to the marginal product times the price level. Transformed this relationship into growth rates the changes of the nominal wages should be equal to the sum of productivity growth and the inflation rate. The coeffcients indicate that unions are more successful to enforce their demands, as the average consumer price inflation is usually higher than for producer prices. The tightness of the labour market does not play a role in most countries, indicating that outsiders have a low weight in the bargaining process. As an exception, the lagged change in the unemployment rate is almost significant at the 0.05 level in Germany. The minor impact of labour market conditions is in line with the results of Dreger and Reimers (2009), who present evidence in favour of hysteresis in the EU and US unemployment rate. In addition, Germany is the only country with substantial persistence in the wage determination process. Thus, nominal wages react more slowly to a changing economic environment.

Although the regression coefficients reveal some variation, the fluctuations do not appear overwhelmingly strong. According to the cusums of squares, the fundamental pat- 
tern to explain the common component has not shifted over time (Figure 2). Finally, it is worth to recall that unions maximize expected income. This implies that they should establish a forward looking behaviour. A test of this hypothesis is to include the leads of inflation and productivity growth in the equation explaining the common component. However, both variables are not significant. In this sense, the relationships do not show signs of forward looking behaviour.

-Figure 2 about here-

\section{$5 \quad$ Conclusions}

This paper provides an empirical analysis on the determination of wages at the sectoral level in main industrial economies. Nominal wages are bargained between labour unions and employers in imperfect competitive markets, where spillovers across sectors might occur. The theoretical model is investigated by a principal component approach, where sectoral wage growth rates are separated into common and idiosyncratic components. In regression models for the common component, national inflation and productivity growth dominate, while labour market tightness is negligible.

Wage spillovers are higher in the continental European, and lower in the Anglosaxon economies. In line with the higher dispersion of wage inflation across sectors, the shares of the common component in the wage determination process have decreased in the second subsample. Increases of nominal wages tend to be more in line with individual conditions like sectoral productivity and output prices, probably due to advances in the

globalization of markets. In general, the weight of the common component is higher for 
the manufacturing than for services sectors. One striking exception is financial intermediation, where the macroeconomic variables are highly weighted. In contrast, the weight is low for public services. Hence, models for wage inflation in the public sector should not be based on economy-wide conditions.

In the euro area, exchange rate and monetary policies are no longer at the disposal of the individual member states. In addition, fewer opportunities for independent fiscal policies limit the capacity to react against adverse shocks. Therefore, the process of wage determination becomes more important for a sound economic development. In particular, a smooth adjustment of wages is required to react to a fast changing environment. This is even reinforced in times of the financial crisis. While nominal wages are bargained between unions and firms or their organizations, policies should not try to reduce the dispersion in the outcome across sectors. 


\section{References}

Addison, J.T., Burton, J. (1979): The identification of market and spillover forces in wage inflation: A cautionary note, Applied Economics 11.

Aukrust, O. (1977): Inflation in the open economy: A Norwegian model, in Krause, L. B., Salant, W. S.: Worldwide inflation: Theory and recent experience, 107-153, Brookings, Washington.

Bai, J., Ng, S. (2002): Determining the number of factors in approximate factor models, Econometrica 70, 191-221.

Bårdsen, G., Eitrheim, Ø, Jansen, E.S., Nymoen, R. (2005): The econometrics of macroeconomic modelling, Oxford University Press, Oxford.

Calmfors, L. (1993): Centralization of wage bargaining and macroeconomic performance - A survey, OECD Economic Studies, 161-191.

Calmfors, L., Drifill, J. (1988): Bargaining structure, corporatism and macroeconomic performance, Economic Policy 6, 13-61.

Coelli, M., Fahrer, J., Lindsay, H. (1994): Wage dispersion and labour market institutions: A cross country study, Discussion Paper 9404, Economic Research Department, Reserve Bank of Australia.

Cukierman, A., Lippi, F. (1999): Central bank interdependence, centralization of wage bargaining, inflation and unemployment - Theory and some evidence, European Economic Review 43, 1395-1434.

Dreger, C, Reimers, H-E. (2009): Hysteresis in the development of unemployment: The EU and US experience, Spanish Economic Review 11, 267-276. 
Du Caju, P., Gautier, E., Momferatou, D., Ward-Warmedinger, M. (2008): Institutional features of wage bargaining in 23 European countries, the US and Japan, ECB Working Paper 974, Frankfurt/M.

Eckstein, O., Wilson, T. (1962): Determination of money wages in the American industry, Quarterly Journal of Economics 76, 379-414.

Estevao, M., Nargis, N. (2005): Structural labor market changes in France, IZA Discussion paper 1621.

Frankel, J.A., Rose, A. (1998): The endogeneity of the optimum currency area criteria, Economic Journal 108, 1009-1025.

Friberg, K. (2003): Intersectoral wage linkages in Sweden, Sveriges Riksbank, Working Paper Series 158.

Graafland, J. J., Lever, M. H. C. (1996): Internal and external forces in sectoral wage formation: Evidence frm the Netherlands, Oxford Bulletin of Ecnomics and Statistics 58, 241-253.

Grüner, H.P., Hefeker, C. (1999): How will EMU affect inflation and unemployment in Europe?, Scandinavian Journal of Economics 101, 33-47.

Heckel, T, Le Bihan, H., Montornes, J. (2008): Sticky wages: Evidence from quarterly microeconomic data, ECB Working Paper 893.

Layard, P.R.G, Nickell, S.J., Jackman, R. (1991) Unemployment: Macroeconomic performance and the labour market, Oxford University Press, Oxford.

Lever, M.H.C., Marquering, W.A (1996): Union coverage and sectoral wages: Evidence from the Netherlands, Empirical Economics 21, 483-499. 
Nickell, S.J., Vainiomaki, J., Wadhwani, S. (1994): Wages and product market power. Economica 61, 457-473.

O’Mahoney, M., Timmer, M. P. (2009): Output, input and productivity measures at the industry level: The EU KLEMS database, Economic Journal 119, F374-F403.

Peeters, M., Den Reijer, A. (2008): On wage formation, wage development and flexibility: A comparison between European countries and the United States, Applied Econometrics and International Development 8, 59-74. 
Table 1: Sectors covered by the analysis

01 Argriculture, hunting, forestry and fishing

$02 \quad$ Mining and quarrying

03 Food, beverages and tobacco

04 Textiles, textile, leather and footwear

05 Wood and of wood and cork

06 Pulp, paper, printing and publishing

07 Chemical, rubber, plastics and fuel

08 Other non-metallic mineral

09 Basic metals and fabricated metal

10 Machinery, Nec

11 Electrical and optical equipment

12 Transport equipment

13 Manufacturing $\mathrm{Nec}$, Recycling

14 Electricity, gas and water supply

15 Construction

16 Wholesale and retail trade

17 Hotels and restaurants

18 Transport and storage

19 Post and telecommunications

20 Financial intermediation

21 Real estate, renting and business activities

22 Public admin and defence, compulsory social security

23 Education

$24 \quad$ Health and social work

25 Other community, social and personal services

Source: EU KLEMS Database. 
Table 2: Sectoral wage growth

\begin{tabular}{|l|l|l|l|l|l|l|}
\hline & & France & Germany & Italy & UK & US \\
\hline $1977-07$ & All & $6.00(0.64)$ & $3.97(0.56)$ & $7.67(0.46)$ & $7.65(1.01)$ & $4.77(0.57)$ \\
& Manufact & $6.41(0.48)$ & $4.29(0.62)$ & $7.03(0.37)$ & $7.56(0.72)$ & $4.57(1.21)$ \\
& Services & $5.50(0.59)$ & $3.64(0.54)$ & $7.44(0.56)$ & $7.54(0.65)$ & $5.08(0.43)$ \\
\hline \hline $1977-90$ & All & $9.74(0.37)$ & $5.04(0.31)$ & $13.0(0.31)$ & $10.9(0.89)$ & $6.06(0.42)$ \\
& Manufact & $10.3(0.33)$ & $5.39(0.29)$ & $11.5(0.31)$ & $11.0(0.31)$ & $5.68(0.38)$ \\
& Services & $8.82(0.40)$ & $4.66(0.25)$ & $12.6(0.36)$ & $10.7(0.60)$ & $6.77(0.34)$ \\
\hline \hline $1991-07$ & All & $3.31(0.83)$ & $3.20(0.74)$ & $3.79(0.57)$ & $5.27(1.10)$ & $3.90(0.67)$ \\
& Manufact & $3.62(0.60)$ & $3.50(0.86)$ & $3.82(0.41)$ & $5.08(1.01)$ & $3.84(1.77)$ \\
& Services & $3.10(0.73)$ & $2.92(0.75)$ & $3.75(0.71)$ & $5.25(0.68)$ & $3.96(0.50)$ \\
\hline
\end{tabular}

Note: Unweighted figures in percent. Entries refer to mean, entries in brackets to the dispersion measured by the coefficient of variation. Overall 25 sectors, 2 agricultural and mining, 13 manufacturing (including construction) and 10 services sectors (including public services). 
Table 3: Principal component analysis of sectoral wage inflation

\begin{tabular}{|l|l|l|l|l|l|l|}
\hline & & France & Germany & Italy & UK & US \\
\hline 1977-07 & All & $75.8 \mid 79.8$ & $64.7 \mid 71.4$ & $82.0 \mid 85.8$ & $49.3 \mid 57.6$ & $49.5 \mid 58.7$ \\
& Manufact & $78.0 \mid 82.8$ & $63.1 \mid 73.5$ & $91.2 \mid 93.7$ & $56.7 \mid 66.8$ & $51.6 \mid 65.3$ \\
& Services & $80.8 \mid 85.7$ & $75.5 \mid 83.0$ & $76.5 \mid 84.7$ & $58.9 \mid 73.1$ & $60.9 \mid 70.5$ \\
\hline $1977-90$ & All & $73.9 \mid 80.2$ & $62.5 \mid 72.1$ & $73.0 \mid 80.4$ & $56.7 \mid 67.7$ & $62.0 \mid 71.3$ \\
& Manufact & $69.2 \mid 78.7$ & $62.2 \mid 74.0$ & $83.0 \mid 88.8$ & $70.0 \mid 81.2$ & $68.0 \mid 77.6$ \\
\hline \hline $1991-07$ & Services & $83.6 \mid 89.8$ & $72.6 \mid 83.7$ & $71.6 \mid 85.9$ & $59.0 \mid 65.6$ & $63.6 \mid 75.7$ \\
& All & $30.0 \mid 43.1$ & $62.2 \mid 70.2$ & $56.0 \mid 65.4$ & $26.5 \mid 40.9$ & $26.6 \mid 46.2$ \\
& Manufact & $38.3 \mid 55.9$ & $60.3 \mid 72.6$ & $73.7 \mid 81.4$ & $31.6 \mid 50.5$ & $31.5 \mid 58.5$ \\
& Services & $41.1 \mid 59.6$ & $75.9 \mid 84.8$ & $38.0 \mid 58.4$ & $33.9 \mid 54.8$ & $31.0 \mid 49.4$ \\
\hline
\end{tabular}

Note: Figures denote cumulative proportion of overall variance attributed to the first two common components. First entry refers to the first; second one to the first two common components. Overall 25 sectors, 2 agricultural and mining, 13 manufacturing (including construction) and 10 services sectors. 
Table 4: Loading coefficients of principal components of sectoral wage inflation

\begin{tabular}{|l|l|l|}
\hline Country & Loading of PC1 & Loading of PC2 \\
\hline France & $0.22(06) \mid 0.22(15)$ & $-0.45(25) \mid 0.39(03)$ \\
\hline Germany & $0.24(16) \mid 0.23(24)$ & $0.60(12) \mid-0.43(17)$ \\
\hline Italy & $0.21(07) \mid 0.21(09)$ & $0.65(20) \mid 0.31(12)$ \\
\hline United Kingdom & $0.25(07) \mid 0.24(22)$ & $0.54(19) \mid 0.36(02)$ \\
\hline United States & $0.26(16) \mid 0.24(09)$ & $0.43(14) \mid 0.35(03)$ \\
\hline
\end{tabular}

Note: First element of each cell gives the value of the highest loading coefficient and second element in cell shows the value of the second highest loading coefficient in the respective principal component (PC). In parentheses are corresponding sector. 
Table 5: Determinants of common component

\begin{tabular}{|c|c|c|c|c|c|}
\hline & FR & GY & IT & UK & US \\
\hline \multirow[t]{2}{*}{$\triangle C P I$} & 0.316 & 0.865 & & 0.715 & 1.152 \\
\hline & $(0.136)$ & $(0.259)$ & & $(0.058)$ & $(0.138)$ \\
\hline \multirow[t]{2}{*}{$\triangle C P I(-1)$} & 0.636 & & 0.778 & & \\
\hline & $(0.138)$ & & $(0.047)$ & & \\
\hline \multirow[t]{2}{*}{$\triangle P R O$} & & & & 0.609 & 0.566 \\
\hline & & & & $(0.147)$ & (0.303) \\
\hline \multirow[t]{2}{*}{$\triangle P R O(-1)$} & 0.772 & 0.658 & 0.371 & & 0.677 \\
\hline & $(0.153)$ & $(0.369)$ & $(0.150)$ & & $(0.340)$ \\
\hline \multirow[t]{2}{*}{$\Delta U(-1)$} & & -0.826 & -0.665 & & \\
\hline & & $(0.479)$ & $(0.429)$ & & \\
\hline \multirow[t]{2}{*}{$P C(-1)$} & & 0.613 & & & \\
\hline & & $(0.133)$ & & & \\
\hline $\mathrm{R} 2$ & 0.965 & 0.798 & 0.935 & 0.857 & 0.736 \\
\hline DW & 1.669 & 2.276 & 1.912 & 1.930 & 1.874 \\
\hline
\end{tabular}

Sample period 1977-2007. OLS regressions of the common component $(P C)$ on their first lag and a set of macroeconomic variables, $P R O=$ hourly labour productivity, $U=$ unemployment rate. $C P I$ and $P R O$ in logs, $\Delta$ first difference operator. Standard errors in parantheses. $R 2=$ Adjusted $R$-squared, DW=DurbinWatson-statistic. 
Figure 1: Common component in wage dermination

France

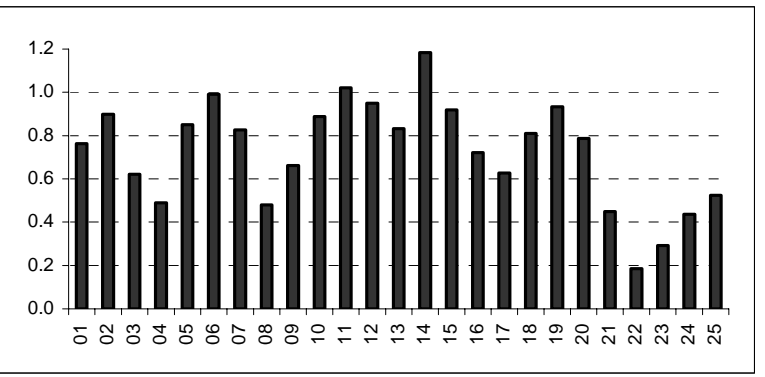

Germany

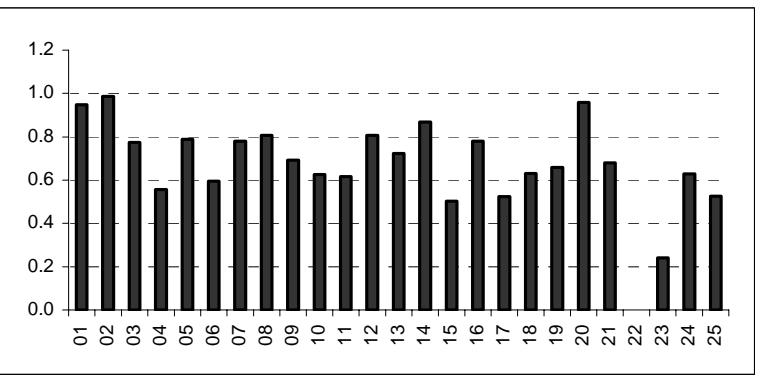

Italy

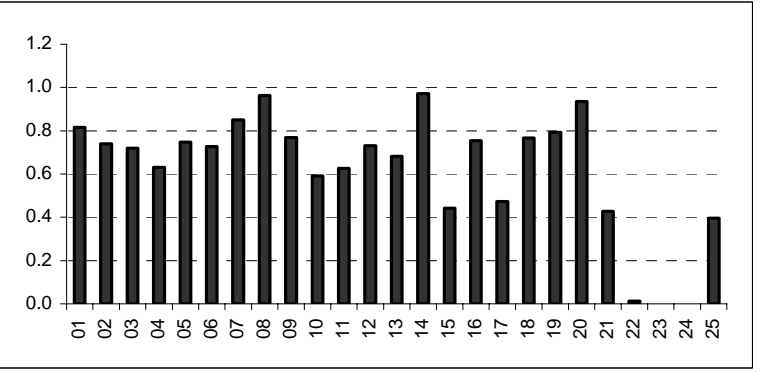

United Kingdom

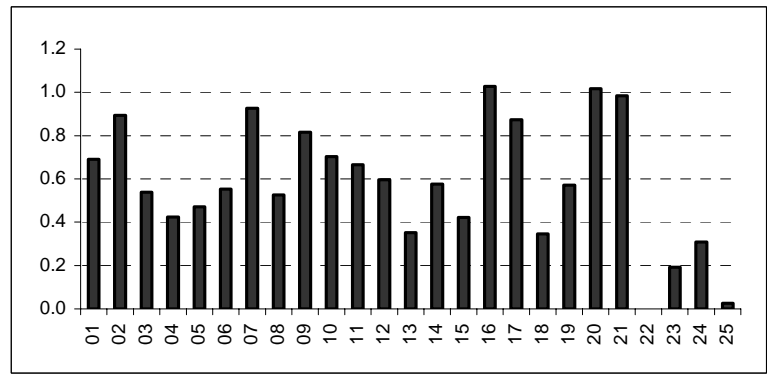




\section{United States}

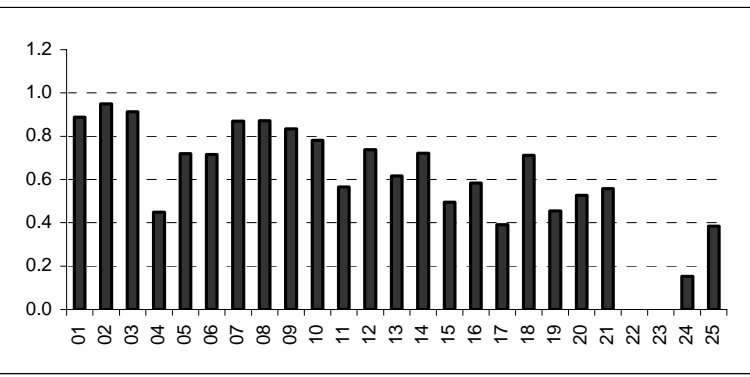

Note: Restricted least squares, 1977-07. Weight of common component in the determination of sectoral wages. Sectoral classification according to table 1. 
Figure 2: Cusums of squares

\section{France}

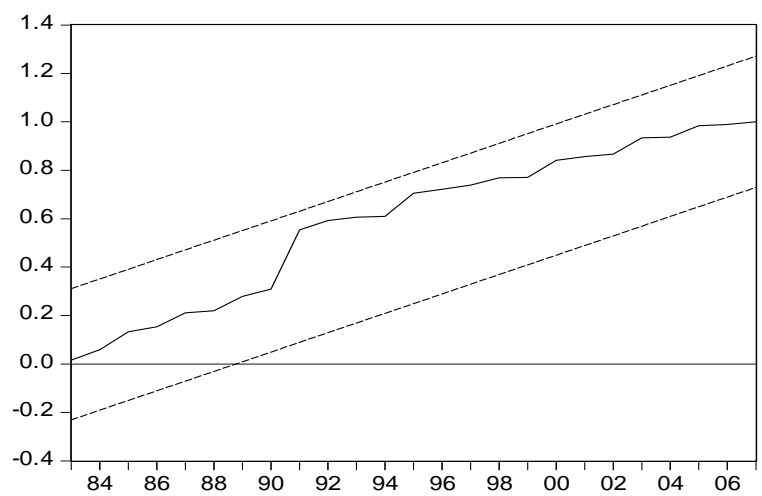

\section{Germany}

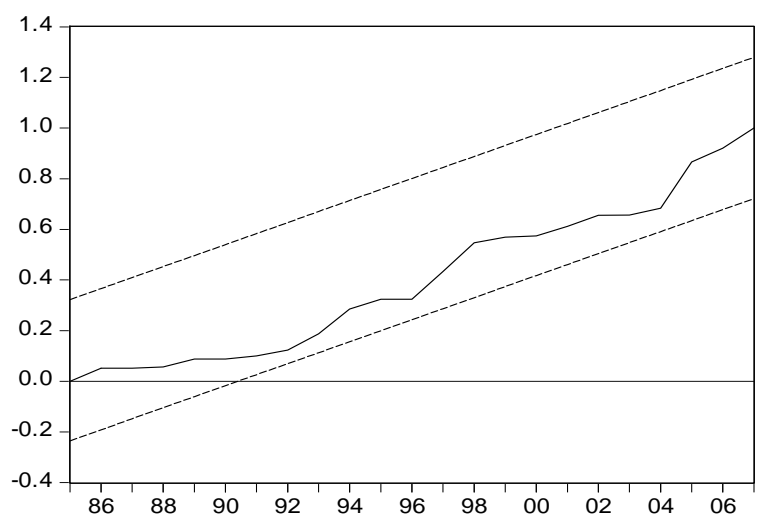

Italy

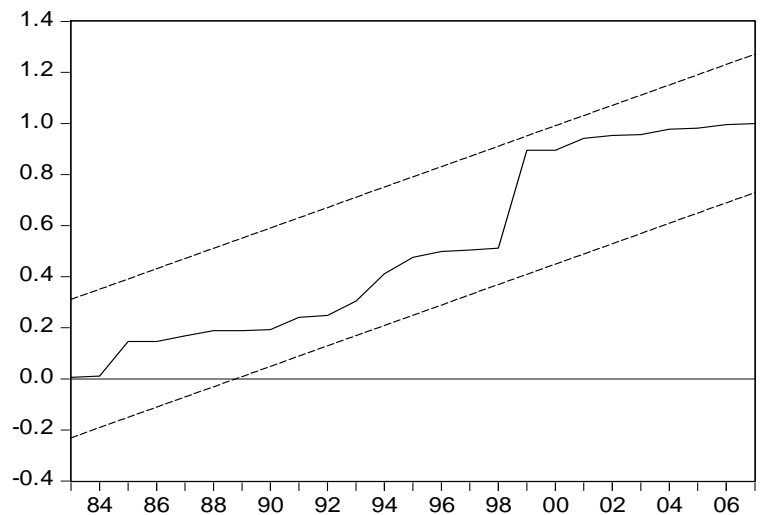




\section{United Kingdom}

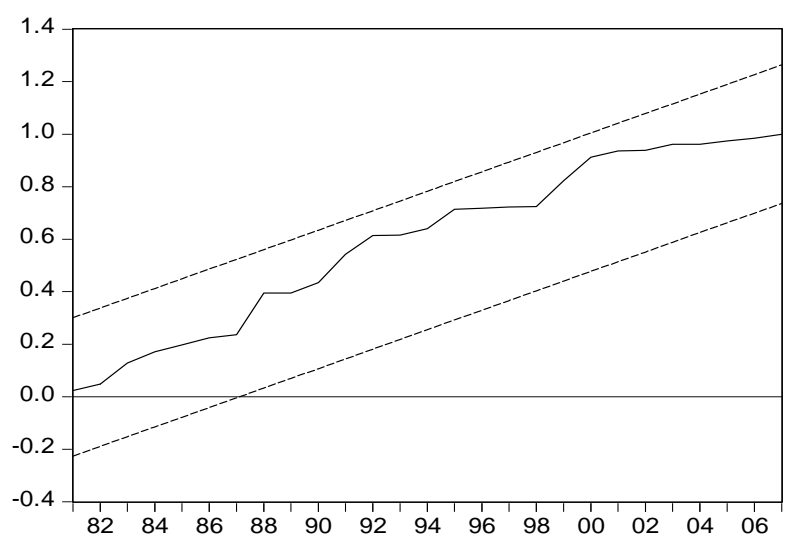

\section{United States}

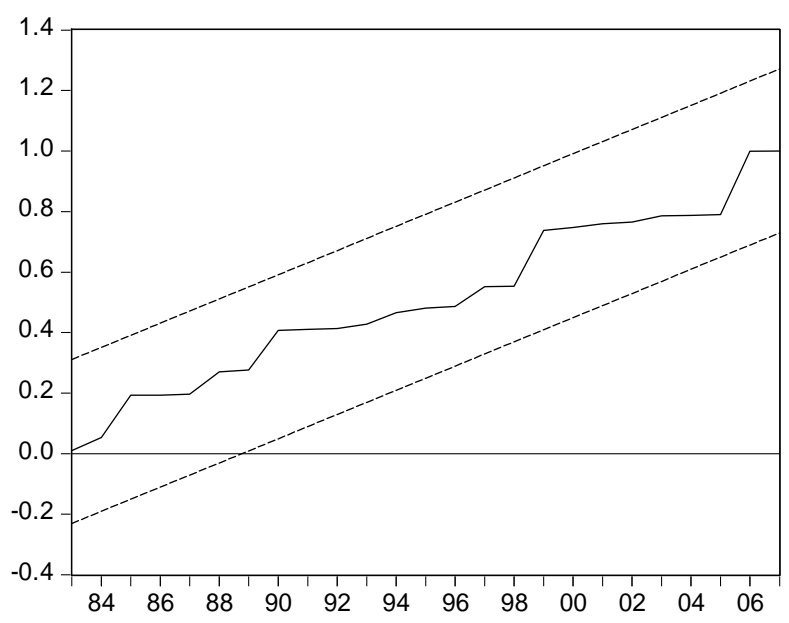

Note: Sample period 1977-2007. Dashed lines represent 0.05 significance levels. 
Appendix: Coefficients of equation (4)

$$
\begin{aligned}
& \lambda=\frac{\frac{\left(1-\alpha \kappa_{i}\right) N_{i} \varepsilon}{\lambda_{d}}}{\lambda_{d}=\frac{W}{W_{i}}[1-\theta(1-b)]+\frac{\left(1-\alpha \kappa_{i}\right) N_{i} \varepsilon}{\left(\varepsilon+\alpha \kappa_{i} / \beta_{i}\right)^{2}(1-\alpha) N_{i}}>0} \\
& \gamma_{1}=\frac{\theta}{1-\theta(1-b)}>0 \\
& \gamma_{2}=\frac{(1-b) \theta}{1-\theta(1-b)}<0 \\
& \gamma_{3}=\frac{\frac{\kappa_{i}}{\lambda_{d}\left(\varepsilon+\alpha \kappa_{i} / \beta_{i}\right)^{2}(1-\alpha) N_{i}}}{\beta_{i}}\left(1+\beta_{i} \varepsilon\right)(1-\alpha) N_{i} \\
& \gamma_{4}=\frac{\alpha \kappa_{i}\left(1-\alpha \kappa_{i}\right)}{\lambda_{d}\left(\beta_{i} \varepsilon+\alpha \kappa_{i}\right)^{2}}>0 \\
& N_{i}(1-\alpha)
\end{aligned}
$$

